Abstracta Iranica Abstracta Iranica

Revue bibliographique pour le domaine irano-aryen

Volume 23 | 2002

Comptes rendus des publications de $\mathbf{2 0 0 0}$

\title{
"A new coin type of the Sasanian king Pêrôz ». Oriental Numismatic Society Newsletter, no. 164 (Summer 2000), pp. 12-13.
}

\section{Rédaction}

\section{(2) OpenEdition}

Journals

Édition électronique

URL : http://journals.openedition.org/abstractairanica/35316

DOI : 10.4000/abstractairanica.35376

ISSN : 1961-960X

Éditeur :

CNRS (UMR 7528 Mondes iraniens et indiens), Éditions de l'IFRI

\section{Édition imprimée}

Date de publication : 15 mai 2002

ISSN : 0240-8910

Référence électronique

Rédaction, « «A new coin type of the Sasanian king Pêrôz ». Oriental Numismatic Society Newsletter, no. 164 (Summer 2000), pp. 12-13. », Abstracta Iranica [En ligne], Volume 23 | 2002, document 100, mis en ligne le 08 février 2010, consulté le 25 septembre 2020. URL : http://journals.openedition.org/ abstractairanica/35316; DOI : https://doi.org/10.4000/abstractairanica.35316

Ce document a été généré automatiquement le 25 septembre 2020.

Tous droits réservés 


\title{
"A new coin type of the Sasanian king Pêrôz ». Oriental Numismatic Society Newsletter, no. 164 (Summer 2000), pp. 12-13.
}

\author{
Rédaction
}

Présentation d'un nouveau type monétaire de Pêrôz en or (1/3 d'un dinar), dont l'avers représente le buste du roi de face portant sa troisième couronne, tandis que le revers montre le dessin normal: l'autel du feu avec deux attendants. Comme motif de la frappe de ce type l'auteur propose une occasion solennelle, peut-être une victoire à cause de laquelle le roi aurait choisi les ailes d'un oiseau de proie, manifestation du dieu Wahrâm, comme nouvel élément de sa couronne.

\section{INDEX}

Thèmes : 3.2.3. Séleucides, Parthes et Sassanides

\section{AUTEURS}

RÉDACTION

Directeur de la revue et secrétariats (Paris et Téhéran) 